\title{
The Nutrient Concentration in Drainage Water in Fertilizer Experiments in Skriveri
}

\author{
Janis Vigovskis, Aivars Jermuss, Daina Sarkanbarde, Agrita Svarta \\ Research Institute of Agriculture of Latvian University of Agriculture \\ Address: Zemkopības institūts 7, Skrīveri, LV-5125, Latvia
}

\begin{abstract}
The paper describes the influence of long term (more than 30 years) fertilizer application to nitrogen, phosphorus, potassium, calcium and magnesium leaching through subsurface drainage in small experimental catchment. The effect of crop and cultivation practice on nutrient concentrations in drainage water is analyzed. This paper presents leaching data during 2011-2013 when spring oilseed rape (OSR), spring barley (SB) and perennial grasses (GC) were grown.

The research has been carried out at the Research Institute of Agriculture of Latvian University of Agriculture in the long-term subsurface drainage field established in Skrīveri in 1981 under the guidance of professor J. Štikāns. The long-term drainage field was established in the uncultivated gleyic sod-podzolic Hypostagnic Endogleyic Albeluvisol (Hypereutric), stw-ng-AB(he) loam that had not been used in agriculture for 20 years before. The experimental field was established with four rates of mineral fertilizers: without fertilizers, N45P30K45; N90P60K90 N135P90K135 calculated in form of $\mathrm{P}_{2} \mathrm{O}_{5}$ and $\mathrm{K}_{2} \mathrm{O}$. Since 1994 a seven-year crop rotation has been organized: 1) winter triticale, 2) potatoes, 3) spring wheat, 4) spring oilseed rape, 5) spring barley + perennial grasses (red clover, timothy), 6) perennial grasses, 1st year of using, and 7) perennial grasses 2 nd year of using. The total area (1.6 ha) of the experimental field was divided into 16 plots $(15 \times 50 \mathrm{~m})$. Each plot was supplied with a seepage tile drain at the depth of $80-100 \mathrm{~cm}$ and an inspection well for drain water sampling and measurement of total water amount.

The nitrate nitrogen content in subsurface drain water was significantly affected by fertilizer rate and crop species. The concentration of nitrogen in drain water was significantly lower from non-fertilised plots than from other treatments and was considerably lower growing grass without autumn soil tillage than with conventional ploughing. Different fertilizer rates (applying 30, 60 or $90 \mathrm{~kg} \mathrm{ha}^{-1}$ of phosphorus and no fertilizer) had no significant effect on phosphorus concentration in drain water. However, concentration of potassium in drain water depended remarkably $(p<0.001)$ on fertilization rate and was lower from non-fertilized plots. Without autumn ploughing and providing vegetation potassium leaching was significantly lower. The use of fertilizers increased the subsurface water concentration of calcium and magnesium considerably.
\end{abstract}

Keywords: drainage water, nitrogen, phosphorus, potassium, calcium, magnesium.

\section{INTRODUCTION}

The results of many scientific findings from the long-term monitoring show large differences in the levels of plant nutrient losses between the catchments and fields with different farming intensity, large annual and interannual variability due to climate impact and soil conditions $[9,11,19]$.

Fresh applications of phosphorus (P) may cause losses of dissolved and particulate $\mathrm{P}$ forms in land runoff when rainfall interacts directly with fertilizers and manures which are spread onto the soil surface. Rates of $\mathrm{P}$ loss are temporally and spatially very variable ( $<1$ to $25 \%$ of total $\mathrm{P}$ applied) depending on the amount of $\mathrm{P}$ applied; the $\mathrm{P}$ release properties of the materials applied (\% P extractable in water), the timing of storm events after application and the amounts of runoff generated. Large $\mathrm{P}$ applications left on the surface of wet, frozen, compacted, and intensively under-drained soils in high rainfall areas are particularly vulnerable to leaching. Concentrations of $\mathrm{P}$ in runoff are often the greatest during the first storm event following $\mathrm{P}$ application, but can remain high for several weeks, or even months after application [26].

Long-term fertilisation experiments have shown that important processes in the large-scale turnover of nitrogen operate on a time scale of decades up to at least a century [6].

The group of scientists [21] from the Baltic Sea region have determined that for the time period 1970 93 there had been substantial changes in land use, atmospheric deposition and wastewater treatment in many parts of the study area. But the total riverine 
loads of nitrogen $(\mathrm{N})$ and phosphorus $(\mathrm{P})$ to the Baltic Sea have been fairly constant since 1980, and most likely also since 1970. Moreover, the interannual variation was clearly correlated to the runoff. The average annual loads to the Baltic Sea for the time period 1980-93 were found to be about 825000 tonnes $\mathrm{N}$ and 41000 tonnes $\mathrm{P}$, respectively. The total annual riverine load from the 117 basins to the Baltic Sea for the years 1994-2006 was estimated to 570000t of $\mathrm{N}$. The results show that around 380000t of $\mathrm{N}$ are annually retained in surface waters draining to the Baltic Sea [20].

The aim of research - to analyze the influence of long term (more than 30 years) fertilizer application to nitrogen, phosphorus, potassium, calcium and magnesium leaching through subsurface drainage.

The hypothesis - the long term fertilizer application influence the nutrient concentration in drainage water.

The paper describes the influence of long term (more than 30 years) fertilizer application to nitrogen, phosphorus, potassium, calcium and magnesium leaching through subsurface drainage in small experimental catchment. The effect of crop and cultivation practice on nutrient concentrations in drainage water is analyzed.

\section{MATERIALS AND METHODS}

\section{Field site}

The research has been carried out at the Research Institute of Agriculture of Latvian University of Agriculture in the long-term subsurface drainage field established in Skrīveri in 1981 under the guidance of professor J. Štikāns.

The long-term drainage field was established in the uncultivated gleyic sod-podzolic Hypostagnic Endogleyic Albeluvisol (Hypereutric), stw-ng-AB(he) (IUSS Working Group WRB, 2007) loam that had not been used in agriculture for 20 years before. After 32 years similar soil parameters showed significantly different content of all nutrients (phosphorus, potassium) related to the different level of fertilizer application (table 1).

TABLE 1

THE NUTRIENT CONTENT IN SOIL

\begin{tabular}{lccccc}
\hline \multicolumn{5}{c}{ THE NUTRIENT CONTENT IN SOIL } \\
& $\mathrm{P}$ & $\mathrm{K}$ & $\mathrm{Ca}$ & $\mathrm{Mg}$ & $\begin{array}{c}\text { Organic } \\
\text { matter, } \\
\mathrm{g} \mathrm{kg}^{-1}\end{array}$ \\
\hline Without & 14 & 29 & 670 & 68 & 22 \\
N45P30K45 & 30 & 74 & 1016 & 128 & 23 \\
N90P60K90 & 78 & 108 & 574 & 41 & 24 \\
N135P90K135 & 181 & 174 & 877 & 78 & 24 \\
\hline
\end{tabular}

The study site is located in the central part of Latvia $\left(56^{\circ} 38^{\prime} \mathrm{N}\right.$; $\left.025^{\circ} 08^{\prime} \mathrm{E}\right)$ with warm temperate climate. The precipitation amount is normally $670 \mathrm{~mm}$ a year. The annual air temperature is $+5.7^{\circ} \mathrm{C}$. The winter average air temperature is $-4.3^{\circ} \mathrm{C}$. The duration of vegetation period proceeds $180-210$ days.

The meteorological conditions were different during research period (Fig.1, Fig. 2.)

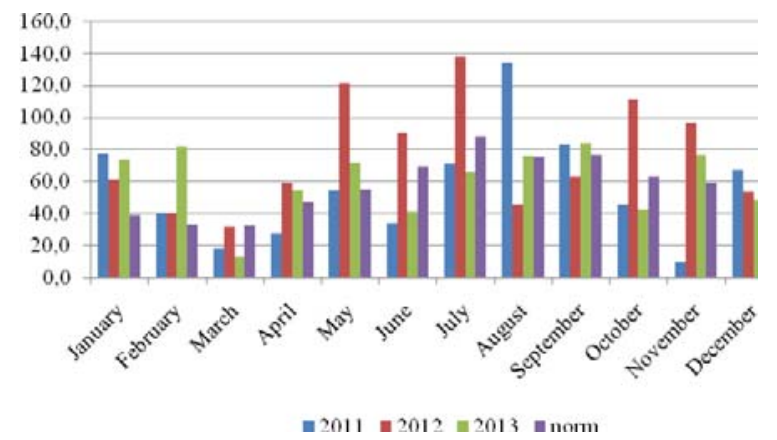

Fig.1. The amount of precipitation, 2011-2013 (Skriveri)

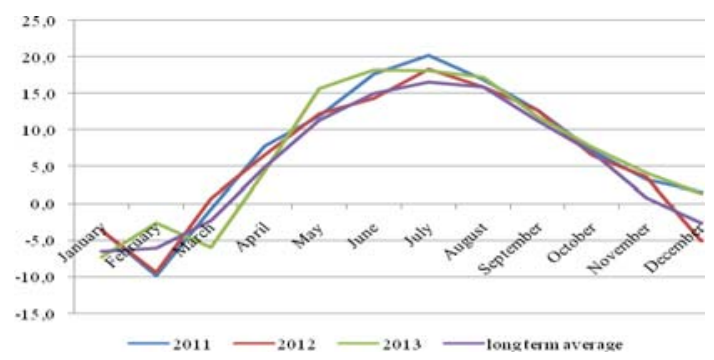

Fig.2. The average temperature of air, 2011-2013 (Skriveri)

\section{Experimental treatments}

The experimental factors were mineral fertilizers, termed ' $F$ '. The experimental field was established with four rates of mineral fertilizers: F0 - without fertilizers, F1 - N45P30K45; F2 - N90P60K90 and $\mathrm{F} 3-\mathrm{N} 135 \mathrm{P} 90 \mathrm{~K} 135$ calculated in form of $\mathrm{P}_{2} \mathrm{O}_{5}$ and $\mathrm{K}_{2} \mathrm{O}$ or $\mathrm{F} 1-\mathrm{N} 45 \mathrm{P} 13 \mathrm{~K} 37$; F2 - N90P26K74 and F3 $\mathrm{N} 135 \mathrm{P} 39 \mathrm{~K} 112$ calculated as elemental $\mathrm{P}$ and $\mathrm{K} \mathrm{kg} \mathrm{ha}{ }^{-}$ 1. Mineral fertilizers were applied according to the anticipated rates of plant nutrient elements annually during the cultivation of soil before sowing. For winter cultivars the phosphorus as superphosphate and potassium as potassium chloride fertilizers were cultivated before the sowing in autumn and nitrogen in form of ammonium nitrate was applied the next spring at the beginning of vegetation and at the stage of tillering.

The total area (1.6 ha) of the experimental field was divided into 16 plots $(15 \times 50 \mathrm{~m})$. Each plot was supplied with a seepage tile drain at the depth of 80$100 \mathrm{~cm}$ and an inspection well for drain water sampling and measurement of total water amount.

\section{Crop management}

This paper presents leaching data during 2011-2013 when spring oilseed rape (OSR), spring barley (SB) and perennial grasses (GC) were grown.

OSR variety Clipper was used in 2011. Soil was ploughed in the autumn before growing OSR. OSR 
was sown at the depth of $1.5-2 \mathrm{~cm}$ and at the row distance of 12-12.5 $\mathrm{cm}$. The sowing was done on the 28 th of April for a target density of 90 plants $\mathrm{m}^{-2}$. For weed control the mixture of herbicides lontrel $72 \mathrm{SG}$ (clopiralid $720 \mathrm{~g} \quad \mathrm{~kg}^{-1}$ ) $0.4 \quad \mathrm{l} \mathrm{ha} \mathrm{ha}^{-1}+$ pantera (quisalophop tephuril $40 \mathrm{~g} \mathrm{l}^{-1}$ ) $1.5 \mathrm{l} \mathrm{ha}^{-1}$ was used at the end of May.

SB variety Anakin was used in 2012. Spring barley was sown at the depth of $2-4 \mathrm{~cm}$ and at the row distance of 12-12.5 $\mathrm{cm}$. The sowing was done on the 8th of May. A day later, the mixture of GC was sown under spring barley. The components of mix include red clover Jancis, timothy Varis, meadow fescue Silva and festulolium Vizule with sowing rate of mix $30 \mathrm{~kg}$ ha $^{-1}$.

\section{Measurements and calculations}

The intensity of drain water flow was measured and water samples were taken. The water sampling was done manually every time the water ran through drains at the start, at maximal and at the end of flow. Since 2010 to measure drain water flow pendulum type automatic water counters with data loggers were installed. Nitrate nitrogen content in drain water was determined by applying LVS ISO 7890-3:2002, phosphorus content - by LVS EN ISO 6878:2005, potassium - by LVS ISO 9964-3:2000, calcium - by LVS ISO 6058:1984 and magnesium - by ISO 6059:1984.

The obtained data mathematical processing was performed using analysis of variance (ANOVA).

\section{RESULTS AND DISCUSSION}

The nitrate nitrogen content in subsurface drain water was significantly affected by fertilizer rate and crop species (Table 2; Table 3). Significant differences were noted when comparing three-year average $\mathrm{N}-\mathrm{NO}_{3}$ concentrations between the highest rate $(\mathrm{F} 3)$, the lowest rates $(\mathrm{F} 1$ and $\mathrm{F} 2)$ and plots with no applied fertilizer (F0) $(\mathrm{P}<0.001$; Table 2$)$. The spring OSR (2011) and spring barley (2012) resulted high nitrate content in subsurface water 11.94 and $12.32 \mathrm{mg} \mathrm{N}-\mathrm{NO}_{3} \mathrm{I}^{-1}$ respectively (Table 2). Growing grass- clover mix (2013) the concentration of nitrate nitrogen in drain water was low and ranged from 4.98 $\mathrm{mg} \mathrm{N}-\mathrm{NO}_{3} \mathrm{l}^{-1}$ (F2) to $5.51 \mathrm{mg} \mathrm{N}-\mathrm{NO}_{3} \mathrm{l}^{-1}$ (F1) except highest fertilization rate (F3) where was $11.03 \mathrm{mg} \mathrm{N}$ $\mathrm{NO}_{3} \mathrm{l}^{-1}$ drain water nitrate content found and it was near to spring cultivars. There was found no interaction between fertilizer and crop species $(\mathrm{P}=0.128>0.05$; Table 3$)$.

Ingrid Wesström, Ingmar Messing [25] write that the high-risk periods for $\mathrm{N}$ losses through drains coincided with periods of high outflow rates and high mineral $\mathrm{N}$ content in soil. The changes in mineral $\mathrm{N}$ content in soil, $\mathrm{NO}_{3}-\mathrm{N}$ loading in drain outflow, $\mathrm{N}$ fertiliser application, $\mathrm{N}$ uptake in crops showed a surplus during autumn in all plots.
TABLE 2

NUTRIENT CONCENTRATION IN DRAIN WATER 20112013 RELATED TO CULTIVATION REGIME AND LONGTERM FERTILIZATION RATE, MG L ${ }^{-1}$

\begin{tabular}{lccccr}
\hline \multicolumn{1}{c}{ Param. } & F0 & F1 & F2 & F3 & average \\
\hline NO3, mg l ${ }^{-1}$ & & & & & \\
OSR (2011) & 10.95 & 11.70 & 11.43 & 13.68 & 11.94 \\
SB (2012) & 10.92 & 11.47 & 12.33 & 14.54 & 12.32 \\
GC (2013) & 5.39 & 5.51 & 4.98 & 11.03 & 6.73 \\
Average & 9.09 & 9.56 & 9.58 & 13.08 & \\
\hline
\end{tabular}

\begin{tabular}{llllll}
\hline $\mathbf{P}_{\mathbf{2}} \mathbf{O}_{\mathbf{5}}, \mathbf{~ m g ~ l}^{-1}$ & & & & & \\
OSR (2011) & 0.004 & 0.005 & 0.004 & 0.003 & 0.004 \\
SB (2012) & 0.004 & 0.005 & 0.004 & 0.004 & 0.004 \\
GC (2013) & 0.008 & 0.008 & 0.009 & 0.010 & 0.009 \\
Average & 0.005 & 0.006 & 0.006 & 0.006 & \\
\hline
\end{tabular}

\begin{tabular}{llllll} 
Average & 0.005 & 0.006 & 0.006 & 0.006 & \\
\hline $\mathbf{K}_{\mathbf{2}} \mathbf{O}, \mathbf{~ m g ~ l}^{-1}$ & & & & & \\
OSR (2011) & 0.13 & 0.23 & 0.30 & 0.25 & 0.23 \\
SB (2012) & 0.10 & 0.18 & 0.28 & 0.31 & 0.22 \\
GC (2013) & 0.10 & 0.13 & 0.13 & 0.18 & 0.13 \\
Average & 0.11 & 0.18 & 0.24 & 0.25 &
\end{tabular}

\begin{tabular}{llllll}
\hline Ca, mg l$^{-1}$ & & & & & \\
OSR (2011) & 58.50 & 49.00 & 63.75 & 66.00 & 59.31 \\
SB (2012) & 63.94 & 88.38 & 73.25 & 98.88 & 81.11 \\
GC (2013) & 72.25 & 87.00 & 77.25 & 99.75 & 84.06 \\
Average & 64.90 & 74.79 & 71.42 & 88.21 & \\
\hline Mg, mg l I $^{-1}$ & & & & & \\
OSR (2011) & 11.50 & 18.75 & 12.50 & 20.50 & 15.81 \\
SB (2012) & 13.94 & 19.69 & 14.81 & 23.56 & 18.00 \\
GC (2013) & 15.25 & 22.25 & 14.00 & 21.50 & 18.25 \\
Average & 13.56 & 20.23 & 13.77 & 21.85 & \\
\hline Rat & & & &
\end{tabular}

Rates of fertilizers: F0 - N0P0K0, F1 - N45P30K45, F2 N90P60K90 and F3 - N135P90K135

OSR - spring oilseed rape; SB - spring barley ; GC - grasses-red clover

During the winter season, a surplus in measured net changes of $\mathrm{N}$ was found in common drainage system in all years. The nitrogen is leached from agricultural soils, even with no $\mathrm{N}$ application By $\mathrm{N}$ application similar to that removed with yields, $\mathrm{N}$ leaching losses amounting to $40-50 \mathrm{~kg} \mathrm{ha}^{-1}$ [24] and $25-30 \mathrm{~kg} \mathrm{ha}^{-1}$ [13] are found [2]. The $\mathrm{N}$ losses were the highest for fields with excessive $\mathrm{N}$ application [3]. Our trials show even after 30 years of experiment from plots with no nitrogen fertilisation the nitrogen is leached by drain water and excessive $\mathrm{N}$ application resulted highest nitrogen concentration in drain water. In Latvia the maximal nitrogen rate for spring barley (at predicted yield 3- $5 \mathrm{t} \mathrm{ha}^{-1}$ ) is limited to $100 \mathrm{~kg} \mathrm{~N} \mathrm{ha}^{-1}$ but for spring oilseed rape (predicted yield $2-4 \mathrm{t} \mathrm{ha}^{-1}$ ) is limited to $120 \mathrm{~kg} \mathrm{~N} \mathrm{ha}^{-1}$.

The content of phosphorus in subsurface drain water was relatively low and average yearly 
concentration ranged from $0.003 \mathrm{mg} \mathrm{P}^{-1}$ (at F3, OSR, 2011 ) to $0.010 \mathrm{mg} \mathrm{P}^{-1}$ (at F3, GC, 2013) of water (Table 2). Statistical differences of $\mathrm{P}$ concentrations in subsurface drainage are presented in Table 2. There were no statistically remarkable differences of phosphorus content in drain water among different fertilizer application rates $(p=0.759>0.05$; Table 3$)$. When comparing phosphorus concentrations between OSR or SB (0.004 $\left.\mathrm{mg} \mathrm{P}^{-1}\right)$ and GC $\left(0.009 \mathrm{mg} \mathrm{P} \mathrm{l}^{-1}\right)$ in average by fertilizer rates, significant differences were noted $(\mathrm{P}=0.008<0.05$; Table 3$)$.

\section{TABLE 3}

ANALYSIS OF VARIANCE P-VALUES FROM CULTIVARS AND FERTILIZER RATES 2011-2013

\begin{tabular}{|c|c|c|}
\hline \multirow{2}{*}{ Source of variation } & \multicolumn{2}{|c|}{ ANOVA values } \\
\hline & $\mathrm{F}_{\text {act }}$ & $\mathrm{P}$ \\
\hline \multicolumn{3}{|l|}{$\mathrm{NO3}, \mathrm{mg} \mathrm{l}^{-1}$} \\
\hline Effect of cultivar (A) & $* *$ & $<0.001$ \\
\hline $\begin{array}{l}\text { Effect of fertilizer rates } \\
\text { (B) }\end{array}$ & $* *$ & $<0.001$ \\
\hline $\mathrm{AxB}$ & n.s. & 0.128 \\
\hline \multicolumn{3}{|l|}{$\mathbf{P}, \mathrm{mg} \mathrm{l}^{-1}$} \\
\hline Effect of cultivar (A) & $* *$ & 0.008 \\
\hline $\begin{array}{l}\text { Effect of fertilizer rates } \\
\text { (B) }\end{array}$ & n.s. & 0.759 \\
\hline $\mathrm{AxB}$ & n.s. & 0.489 \\
\hline \multicolumn{3}{|l|}{$\mathrm{K}, \mathrm{mg} \mathrm{I}^{-1}$} \\
\hline Effect of cultivar (A) & $*$ & 0.001 \\
\hline $\begin{array}{l}\text { Effect of fertilizer rates } \\
\text { (B) }\end{array}$ & $*$ & 0.000 \\
\hline $\mathrm{AxB}$ & n.s. & 0.216 \\
\hline \multicolumn{3}{|l|}{$\mathrm{Ca}, \mathrm{mg} \mathrm{l}^{-1}$} \\
\hline Effect of cultivar (A) & $* *$ & $<0.001$ \\
\hline $\begin{array}{l}\text { Effect of fertilizer rates } \\
\text { (B) }\end{array}$ & $* *$ & $<0.001$ \\
\hline $\mathrm{AxB}$ & $*$ & 0.017 \\
\hline \multicolumn{3}{|l|}{$\mathrm{Mg}, \mathrm{mg} \mathrm{l}^{-1}$} \\
\hline Effect of cultivar (A) & $*$ & 0.008 \\
\hline $\begin{array}{l}\text { Effect of fertilizer rates } \\
\text { (B) }\end{array}$ & $* *$ & $<0.001$ \\
\hline $\mathrm{AxB}$ & n.s. & 0.506 \\
\hline
\end{tabular}

In long-term grassland trials there was no significant change in total soil $\mathrm{P}$ between any of the treatments, although there was a significant decrease in total inorganic $\mathrm{P}$ on two of the sites accompanied by an increase in the organic $\mathrm{P}$ pool, suggesting that over time $\mathrm{P}$ was becoming occluded within organic matter, reducing the plant availability [5]. This could be one of the ways for phosphorus accumulation in soil and limited leaching through drains.

In Italian soils long-term factors influencing the mobility of $\mathrm{P}$ within the soil profile are due not only to excessive $\mathrm{P}$ inputs, but also the forms of $\mathrm{P}$ fertilizer applied [17]. Some results suggest enhanced P losses through subsurface runoff on heavy soils, once a certain plow layer concentration of critical level is exceeded [7,8]. Probably in our experiment in 30 years there is still no critical $\mathrm{P}$ concentration in plow layer reached. The results of Norwegian scientists illustrated that losses of phosphorus (P) and nitrogen (N) had often different critical source areas. The $\mathrm{P}$ losses were highest for fields with manure application and/or high soil P status or with autumn ploughing [3]. Reduced nutrient application and stubble during autumn and winter led to the largest decrease in nutrient losses, and it was also apparent that management changes in high-risk areas had the greatest impact on the indices [3] and our results show similar trend especially for nitrogen and potassium. Marianne E. Bechmann and Johannes Deelstra [1] say that soil phosphorus status in addition to soil erosion is an important factor for phosphorus transfer. Highrisk periods of phosphorus losses from common drainage system did not exclusively occur in months with highest outflow rates. In 3 out of 4 years, peak P loads occurred in late winter and $\mathrm{P}$ concentrations were positively correlated to soil temperature [25].

The results of water sample analysis showed remarkable $(\mathrm{P}=0.001<0.05$, Table 3$)$ influence of fertilization rate on content of potassium in leaching drain water. The highest content of potassium in drain water was observed in the catchment area with high rate (F3) of fertilizers and it had statistically significant $(\mathrm{p}<0.05)$ difference. The highest leaching of potassium was noted in spring OSR plots, where the content of potassium in subsurface drain water rose considerably: from 0.10 in plots with no fertilizer to $0.31 \mathrm{mg} \mathrm{K}^{-1}$ in plots fertilized with rate $\mathrm{F} 3$ $(\mathrm{P}<0.05)$.

Perennial grasses (GC) in average resulted lowest potassium leaching through drains where the content of potassium in water ranged from $0.10 \mathrm{mg} \mathrm{l}^{-1}$ without fertilizer (F0) to $0.18 \mathrm{mg} \mathrm{K}^{-1}$ in the catchment area with the highest fertilizer rate (F3) with calculated average $0.13 \mathrm{mg} \mathrm{K} \mathrm{l}^{-1}$ of drain water (Table 3 ).

The content of calcium in leaching water was variable $(p<0.05$; Table 3$)$. On average by fertilizer rates the lowest content of calcium in drain water was observed in 2011 growing spring OSR: $59.31 \mathrm{mg} \mathrm{Ca}$ $1^{-1}$ and this was significantly lower $(\mathrm{p}>0.05)$ than $81.11 \mathrm{mg} \mathrm{Ca}^{-1}$ at SB and $84.06 \mathrm{mg} \mathrm{Ca}^{-1}$ at GC. The content of calcium in leaching water in average ranged from $64.90 \mathrm{mg} \mathrm{Ca}^{-1}$ without treatment of fertilizers to - $88.21 \mathrm{mg} \mathrm{Ca} \mathrm{l}^{-1}$ (Table 2) and its mean that fertilization rates considerably increased content of calcium in drainage water $(\mathrm{P}<0.001$, Table 2$)$.

The content of magnesium in drain water significantly variated by the different fertilizer rates $(\mathrm{P}<0.05$; Table 3$)$. The content of magnesium varied within the range on average from 11.50 to $22.25 \mathrm{mg} \mathrm{l}^{-1}$ $\mathrm{Mg}$ (Table 3). Variation of magnesium concentration 
in drain water was more influenced by fertilizer rate than growing year or cultivar what was still significant with statistically significant impact $(\mathrm{P}=0.008$, Table $3)$.

Calcium and magnesium cations are leached from the soil most intensively. The succession of vertical migration intensity of soil elements is as follows: $\mathrm{Na}>$ $\mathrm{Ca}>\mathrm{Mg}>\mathrm{K}$ [13]. The results obtained from the longterm (1972-1995) lysimetric experiments conducted in Lithuania suggest that the amounts of calcium and magnesium leached from the soil depend not on the amount of water moving through the soil, but on the level of calcium and magnesium content in the soil, therefore the largest amounts of these elements are leached from heavy-textured calcareous soils [23]. Fertilisation increased the migration of magnesium in soil as well, but the concentrations of magnesium in lysimetre water were lower, since magnesium is retained by soil particles more strongly than calcium [22].

Our results show that fertilization rates considerably increased content of calcium in drain water. The reason for that could be the high Ca-release within the process of higher soil organic matter mineralization. Higher fertilization rates resulted higher crop residues returned to the soil. It is consistent with report of the data obtained from the long-term (1992-2003) experiments conducted in Western Lithuania suggest that the largest annual amounts (on average $112.7 \mathrm{~kg} \mathrm{ha}^{-1}$ ) of calcium were leached from the limed experimental plots treated with mineral and organic fertilisers. The amounts of calcium leached from these plots were larger by $21.3 \%$ than those of calcium leached from the not limed and not fertilised experimental plots [12]. Nitrogen fertilizer at rate of $150 \mathrm{~kg} \mathrm{~N} \mathrm{ha}^{-1}$ results significantly in the highest value of calcium leaching [15]. Soil $\mathrm{pH}$ had a strong influence on $\mathrm{Ca}^{2+}$ and $\mathrm{Mg}^{2+}$ concentrations in the leaching water [4,18]. Monaghan et al. [15] found that $\mathrm{N}$ fertilizer application significantly increased losses of nitrate- $\mathrm{N}$ and $\mathrm{Ca}$ in drainage but had no significant effect on $\mathrm{K}, \mathrm{Mg}, \mathrm{Na}$, sulfate- $\mathrm{S}, \mathrm{Cl}$, and $\mathrm{P}$ drainage losses. Our results show significant increase of content of calcium and magnesium in drain water with fertilizer use.

The inputs of nutrients should be based on realistic crop yield expectations that vary with soil properties. Proper management helps avoid excessive levels of elements such as nitrogen and phosphorus that then become harmful.

\section{CONCLUSIONS}

The concentration of nitrogen in leached drain water was significantly lower from non-fertilised plots than from other treatments and was considerably lower growing grass without autumn soil tillage than with conventional ploughing.
The content of phosphorus in drain water was more influenced by crops and agricultural practice including climatic condition of the year than used fertilizer rate.

Exchangeable potassium in soil has increased more than 4 times (from 64 till $223 \mathrm{mg} \mathrm{K}_{2} \mathrm{O} \mathrm{kg}$ ) and significantly affected drain water content of potassium.

\section{ACKNOWLEDGEMENTS}

This work was supported by the European Regional Development Fund within the project Development of Technology of Reduction of Environmental Pollution Using Mineral Fertilizers (No. 2010/0232/2DP/2.1.1.1.0/10/APIA/VIAA/097).

\section{REFERENCES}

[1] Bechmann M., Deelstra J. Source areas of phosphorus transfer in an agricultural catchment, south-eastern Norway. Acta Agriculturae Scandinavica, Section B - Soil \& Plant Science 56(4), 2006, pp. 292-306

[2] Bechmann M., Greipsland I., Ogaard A.F. Phosphorus use in agriculture. In:Bechmann M., Deelstra J. editors. Agriculture and environment - long-term monitoring in Norway, Akademika publishing, 2013, pp 69-82.

[3] Bechmann M., Stålnacke P., Kværnø S., Eggestad H.O., Øygarden L. Integrated tool for risk assessment in agricultural management of soil erosion and losses of phosphorus and nitrogen. Science of The Total Environment 407(2), 2009, pp 749-759.

[4] Butkute R. Calcium and magnesium concentrations in the leachate from permanent meadow soils. Sustainable grassland productivity. Proceedings of the 21st General Meeting of the European Grassland Federation; April 3-6; Badajoz (Spain), 2006, pp 718-720

[5] Dodd R. J., McDowell R. W. , Condron L. M. Changes in soil phosphorus availability and potential phosphorus loss following cessation of phosphorus fertiliser inputs. Soil Research 51(5), 2013, pp. 427-436.

[6] Grimvall A., Stålnacke P., Tonderski A. Time scales of nutrient losses from land to sea - a European perspective. Ecological Engineering 14(4), 2000, pp. 363-371.

[7] Heckrath G., Brookes P. C., Poulton P. R., Goulding K. W. T. Phosphorus leaching from soils containing different phosphorus concentrations in the Broadbalk experiment. Journal of Environmental Quality 24(5). 1995, pp. 904-910

[8] Horta M.C., Torrent J. The Olsen P method as an agronomic and environmental test for predicting phosphate release from acid soils. Nutrient Cycling in Agroecosystems 77, 2007, pp. 283292.

[9] World reference base for soil resources 2006 http://www.fao.org/fileadmin/templates/nr/images/resources/pd f_docuents/wrb2007_red.pdf

[10] Jansons V. Abramenko K., Bērziña L., Timbare R. Risk assessment of the agricultural pollution with nitrates in Latvia. Proceedings of the Latvian University of Agriculture 22, 2009, pp. $1-11$.

[11] Jansons V., Lagzdiņs A., Bērziņa L., Sudārs R., Abramenko K. Temporal and spatial variation of nutrient leaching from agricultural land in Latvia: long term trends in retention and nutrient loss in a drainage and small catchment scale. Scientific Journal of Riga Tehnical University: Environmental and Climate Tehnologies 13, 2011, pp. 54-65.

[12] Jouany C., Colomb B., Bosc M. Long-term effects of potassium fertilization on yields and fertility status of calcareous soils of south-west France. European journal of agronomy 5( 3-4), 1996, pp 287-294. 
[13] Končius D., Ožeraitienė D., Piaulokaitè-Motuzienè L., Katutis $\mathrm{K}$. The effect of long-term antropogenic load on the properties of Albeluvisol. Vagos. 80(33), 2008, pp. 33-39. (Lithuanian).

[14] Mažvila J. Agrochemical properties of Lithuanian soils and their change: a monograph / compiled by Mažvila J. Lithuanian Institute of Agriculture, 1998, pp. 37-49 (Lithuanian)

[15] Mesić M., Kisić I., Bašić F., Butorac A., Zgorelec Ž., Gašpar I. Losses of $\mathrm{Ca}, \mathrm{Mg}$ and $\mathrm{SO}^{2-} \mathrm{S}$ with drainage water at fertilisation with different nitrogen rates. Agriculturae Conspectus Scientificus. 72(1), 2007, pp. 53-58.

[16] Monaghan R. M., Paton R. J., Smith L. C., Drewry J.J., LittlejohnR. P. The impacts of nitrogen fertilisation and increased stocking rate on pasture yield, soil physical condition and nutrient losses in drainage from a cattle-grazed pasture. New Zealand Journal of Agricultural Research 48(2), 2005, pp. 227-240.

[17] Pizzeghello D., Berti A., Nardi S., Morari F. Phosphorusrelated properties in the profiles of three Italian soils after longterm mineral and manure applications. Agriculture, Ecosystems and Environment 189, 2014, pp. 216-228.

[18] Ristimaki L. Potassium and magnesium fertiliser recommendations in some European countries. The International Fertilizer Society; Proceedings No. 620. 2007; York (UK), pp. 32.

[19] Stålnacke P., Grimvall A., Sundblad K., Tonderski A. Estimation of riverine loads of nitrogen and phosphorus to the Baltic Sea, 1970-1993. Environmental Monitoring and Assessment 58(2), 1999, pp. 173-200.
[20] Stålnacke P., Pengerund A., Vassiljev A., Smedberg E., Mörth C.-M., Hägg H. E., Humborg C. Andersen H. E. Nitrogen surface water retention in the Baltic Sea drainage basin. Hydrology Earth System Sciences 11, 2014, pp. 10829-10858.

[21] Stålnacke P., Vagstad N., Tamminen T., Wassmann P., Jansons V., Loigu E. Nutrient runoff and transfer from land and rivers to the Gulf of Riga. Hydrobiologia. 410(0), 1999a, pp. 103110.

[22] Tripolskaja L. Organic fertilisers and their effect on the environment: a monograph. Lithuanian Institute of Agriculture, 2005, 216 (Lithuanian).

[23] Tripolskaja L., Janušienè V. Management of agroecosystem components. Results of long-term agrochemical experiments: a monograph/ compiled by Tripolskaja L. et al. Lithuanian Research Centre of Agriculture and Forestry, 2010, pp. 282288 (Lithuanian)

[24] Uhlen G. The leaching behaviour and balances of nitrogen and other elements of spring wheat in lysimeter experiment 19851992. Acta Agriculturae Scandinavica. Section B, Soil and Plant Sci. 44, 1994, pp. 201-207.

[25] Wesström I., Messing I. Effects of controlled drainage on N and $\mathrm{P}$ losses and $\mathrm{N}$ dynamics in loamy sand with spring crops. Agricultural Water Management. 87(3, 16), 2007, pp. 229-240.

[26] Withers P., Ulén B., Stamm Ch., Bechmann M. Incidental phosphorus losses - are they significant and can they be predicted? Journal of Plant Nutrition and Soil Science. 166(4), 2003, pp. 459-468. 